\title{
Notes on the typification of three names in the genus Arundinella Raddi (Poaceae)
}

\author{
Shubham Jaiswal ${ }^{1,2}$, Shailja Tripathi ${ }^{1}$, Dileshwar Prasad ${ }^{1}$, Rekha Yadav $^{1,2}$, Virendra K. Madhukar ${ }^{2} \&$ \\ Priyanka Agnihotri ${ }^{1^{*}}$ \\ ${ }^{1}$ Plant Diversity, Systematics and Herbarium Division, CSIR- National Botanical Research Institute, Rana Pratap Marg, Lucknow, India 226001 \\ ${ }^{2}$ Department of Botany, D.D.U. Gorakhpur University, Gorakhpur, India 273009 \\ *Email: priyagni_2006@yahoo.co.in
}

\section{ARTICLE HISTORY}

Received: 04 March 2021

Accepted: 05 May 2021

Available online: 01 July 2021

KEYWORDS

Taxonomy; Endemism; Arudinelleae; Typification

\section{ABSTRACT}

In the present study, lectotypes for three names in the genus Arundinella Raddi are designated. Lectotypification of A. intricata and second-step lectotypification of A. laxiflora and A. mesophylla has been done. Additionally, the geographic distribution of endemic species, A. mesophylla is also provided.

\section{Introduction}

Arundinella Raddi, belonging to the subfamily Panicoideae, tribe Arundinelleae (Poaceae) (1, 2), is mainly distinguished by possessing panicled inflorescence, having paired and two flowered spikelets with an entire or 2-lobed or 2-aristate and scabrid upper lemma. The genus comprises of ca 52 species (3), distributed in tropical and subtropical regions of the world, mainly in Asia (4). From British India, Hooker (5) recorded ca 24 species, thereafter, Bor $(6,7)$ thoroughly revised the genus from India, Myanmar, Pakistan and Sri Lanka and reported ca 23 species. He synonymised some names cited by Hooker and updated the status of a few varieties up to the species level. Nearly two decades ago, Moulik (8) recognised 21 species from India. In the recent past, some new taxa have also been added from India by different workers (9-13). Recently, from India, it was reported that there are 25 species within the genus Arundinella (14). In conformity with earlier published literature, it can be concluded that at present, ca 26 species (5-14) of genus Arundinella are known within India's current political boundaries, of which 13 species are endemic (10-15).

We came across three names during our ongoing revisionary studies in the family Poaceae from Western Himalaya, including an endemic species viz. Arundinella intricata Hughes, A. laxiflora Hook. f. and
A. mesophylla Nees ex steud (endemic to India), which remain surrounded by ambiguity in typification and hence hinder the precise application of these names. To promote nomenclatural stability of these three names, lectotypes have been designated here from the available original material following Art. 9.3 and Art. 9.17 of the Shenzhen Code (16).

\section{Materials and Methods}

During the present study, an extensive literature survey including the protologue of each name and critical analysis of the herbarium specimens has been carried out. Various herbaria such as A, BM, BR, CAL, CGE, DD, E, FI, G, LINN, LIV, LE, KIEL, MICH, MO, NY, OXE, $\mathrm{P}, \mathrm{K}$ and $\mathrm{W}$ were scrutinised to locate the original material (17). Apart from this, different online databases including BHL, IPNI, JSTOR Global Plants, POWO, TROPICOS, WCVP were also consulted to collect all the information helpful for the errorless typification. The specimen best matching with the protologue is selected here as the lectotype for the corresponding names.

\section{Results and Discussion}

Arundinella intricata Hughes in Bull. Misc. Inform. Kew 3: 112.1920 (Fig. 1). 
Type (lectotype designated here):-INDIA, Meghalaya, East Khasi Hills, Mahadeo, $3000 \mathrm{ft}, 22$ October 1871, C.B. Clarke 15622 [K000245501 (digital image!)].

Residual syntypes:-INDIA, Meghalaya, East Khasi Hills, Mawsmai, 4000 ft, 23 October 1871, CB Clarke 16588 [K000245500 (digital image!)]; Amwee, 4000 $5000 \mathrm{ft}$, JD Hooker s.n. [K000245503 (digital image!)];

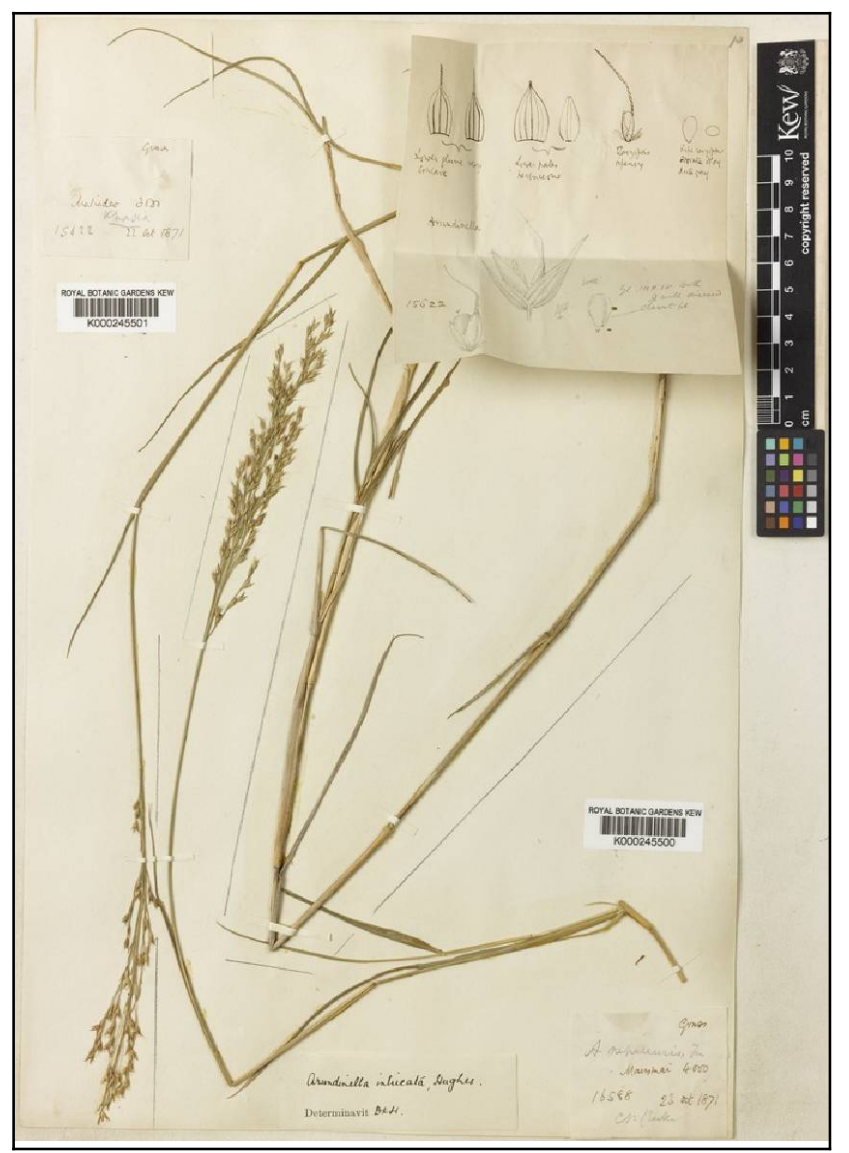

Fig. 1. Lectotype of Arundinella intricata Hughes (barcode K000245501). [C The Board of Trustees of the Royal Botanic Gardens, Kew. Reproduced with the consent of the Royal Botanic Gardens, Kew].

Assam, Tinsukia, Boga-panee, 4000-6000 ft, 02 August 1850, JD Hooker 2001 [K000245502 (digital image!)]; Arunachal Pradesh, Dibang river bank near Rotung, 700 ft, 24 December 1911, IH Burkill 37371 (CAL0000002080!).

Notes:-Arundinella intricata was described by Hughes (18). In the protologue along with diagnosis and description, a total of five gatherings viz. Clarke 155622 [sic!] and 16588, Hooker s.n. and 2001, and Burkill 373 [sic!] were cited. However, he didn't specify any herbarium where these collections were deposited, nor did he choose any specific specimen as holotype. As stated (19), Hughes's type specimens are mainly deposited in K. Therefore, attempts were made to locate original material at $\mathrm{K}$ and CAL (The reason for attempting CAL is that the Burkill's collection from Arunachal Pradesh, India and duplicates of Clarke's and Hooker's collections are deposited here). As a result, we could locate five specimens of which four are deposited at $\mathrm{K}$ (K000245500, K000245501, K000245502 and K000245503) and one at CAL (CAL0000002080).
Specimens with barcode K000245500 and K000245501, collected by Clarke, mounted on the same sheet, represent two different collections (Clarke 16588 and Clarke 15622, respectively). Both specimens bear a label carrying information about type locality, altitude, collection number and date in Clarke's handwriting. Additionally, a determinative slip by Hughes is also present. It seems that Clarke was not quite sure about the identity of these specimens, however, he misapplied the name Arundinella nepalensis Trin. (20) for K000245500. Moreover, K000245501 contains a drawing of dissected spikelet parts, but Clarke still couldn't conclude its identity and wrote "Arundinella" for it. Later, Hughes recognised both specimens as $A$. intricata. Hooker and Thomson collected the remaining two $\mathrm{K}$ specimens with barcode K000245502 (Hooker 2001) and K000245503 (Hooker s.n.). Both specimens bear a label having details of the collection and were identified as $A$. nepalensis Trin. All these specimens were verified later by Hughes as $A$. intricata. The specimen deposited at CAL carrying annotation by Hughes is only found specimen of $A$. intricata extant from Burkill's gathering. However, the collection number 373 [sic!] cited by Hughes in the protologue is a lapsus for Burkill's collection number 37371. Since all these specimens are part of the original material and are therefore considered as syntypes (Art. 9.4 and 9.6 of the ICN) (16). All the above specimens are morphologically compatible with the protologue and were seen by the original author. We select here the specimen K000245501 (Clarke 15622) as lectotype (Art. 9.3 of ICN) (16) because it has a drawing of dissected spikelet parts (made by Clarke), which corresponds well with the description given in protologue.

Arundinella laxiflora Hook. f. in Hook. f., Fl. Brit. India 7: 75.1896 (Fig. 2).

Type (lectotype, first-step designated by Bor 1955: 403):-SRI LANKA (Ceylon), Central Province, 3000$5000 \mathrm{ft}$, GHK Thwaites CP 919 (K, two sheets); Type (lectotype, second-step designated here):-SRI LANKA (Ceylon), Central Province, 3000-5000 ft, GHK Thwaites CP-919 [K000245955 (digital image!)], isolectotypes BR0000006864804 (digital image!), CAL0000002088!, CAL0000002089!, E00393759 (digital image!), K000245493 (digital image!), W18890064918 (digital image!), W18890098353 (digital image!), W19160038668 (digital image!).

Residual syntypes:-SRI LANKA (Ceylon), G. Gardner 1007 [BM000959690 (digital image!), W19160038666 (digital image!)]

Notes:-Hooker described Arundinella laxiflora based on two different gatherings from Sri Lanka i.e., Gardner 1007 and Thwaites C.P. 919 (5). However, he neither selected any specimen as type nor specified the herbaria where these specimens were kept. As per Art. 9.4 and 9.6 of the ICN (16), all the specimens under these gatherings are original material and would be considered as syntypes. After a thorough search, we located 11 sheets of original material housed at BM, BR, CAL, E, K and $\mathrm{W}$ of which nine belong to Thwaites C.P. 919 and the remaining two to 


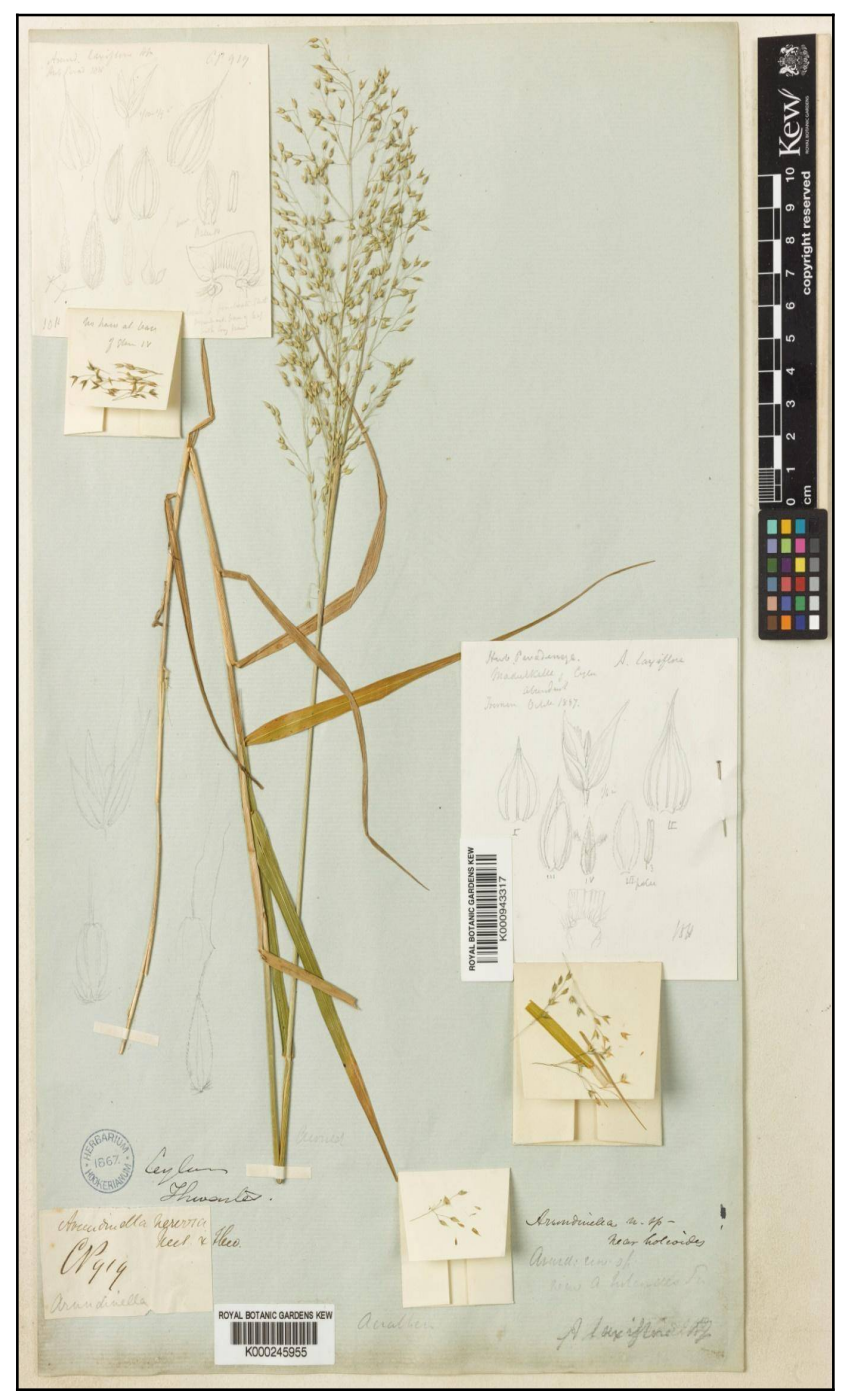

Fig. 2. Lectotype of Arundinella laxiflora Hook. f. (barcode K000245955). [( The Board of Trustees of the Royal Botanic Gardens, Kew. Reproduced with the consent of the Royal Botanic Gardens, Kew].

Gardner 1007. On studying relevant literature, we found that Bor (6) designated Thwaites' material as type [Thwaites C.P. 919 (Typus in Herb. Kew.)]. However, in K, we found two sheets of C.P. 919. The existence of two sheets warrants subsequent typification. Therefore, as per Art 9.17 of the Shenzhen Code (16), second step lectotypification is done here. On these two sheets, three specimens of $A$. laxiflora were mounted, but only two specimens with barcodes K000245493 and K000245955 belong to the Thwaites' collection and therefore constituted the original material. The specimen with barcode K000245955 is designated here as the lectotype of $A$. laxiflora because it perfectly matches with the protologue, displaying inflorescence, culm and leaves and has a pencil sketch of dissected spikelet parts probably drawn by Hooker.

Arundinella mesophylla Nees ex Steud. in Syn. Pl. Glumac. 1: 115. (1854) (Fig. 3).

Type (lectotype, first-step designated by Bor 1955: 394):- INDIA, Tamil Nadu, Courtallam, Wallich 8663B (K, three sheets); Type (lectotype, second-step designated here):-INDIA, Tamil Nadu, Courtallam, Wallich 8663B [K001131148 (digital image!)], isolectotypes K000245479 (digital image!), K000245480 (digital image!).

Distribution:-INDIA: Karnataka, Kerala and Tamil Nadu (endemic to India) (14).

Notes:-Nees (21) described Arundinella mesophylla based on Wallich catalogue number 8663B (22) without indicating any herbarium where the original material was deposited. According to Stafleu and Cowan (23), the main set of Wallich's collection is deposited at Kew (K and K-W) and further materials are available at different herbaria such as A, BM, BR, C, CAL, CGE, DD, E, FI, G, FH, L, LE, LINN, LIV, LE, KIEL, MICH, MO, NY, OXE, P, K, and W. After a thorough search at these herbaria, we could locate three specimens of A. mesophylla bearing Wallich catalogue number 8663B deposited at $\mathrm{K}$. While revising the genus from India, Burma, Ceylon and Pakistan, Bor (6) designated 'catalogue number 8663B' deposited at $\mathrm{K}$ as the type of $A$. mesophylla but didn't specify the sheet. Therefore, the name requires a second step lectotypification (Art. 9.17 of ICN) (16). This is done by narrowing the choice to a single specimen. Out of three sheets, two (K000245479 and K000245480) bear a handwritten label by Wallich, while it is lacking in one (K001131148) of it. However,

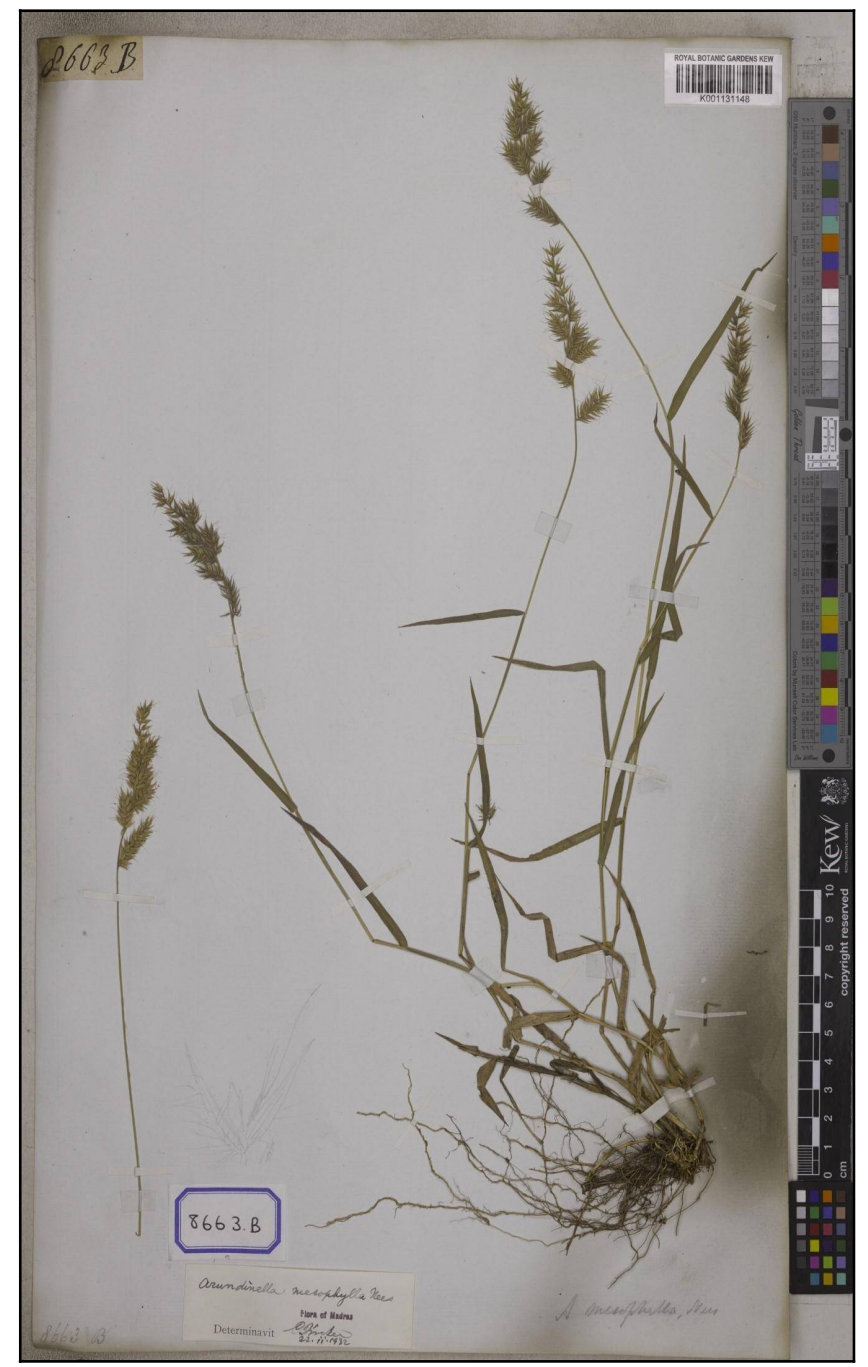

Fig. 3. Lectotype of Arundinella mesophylla Nees ex Steud. (barcode K001131148). [〔 Gardens, Kew. Reproduced with the consent of the Royal Botanic Gardens, Kew]. 
the specimen K001131148 is a perfect and well mounted specimen, agrees well with the protologue and comparatively the best representative of the species. Keeping this in view, here, we designate the specimen with barcode K001131148, as lectotype of the name $A$. mesophylla Nees ex steud.

\section{Acknowledgements}

We acknowledge the Director, CSIR-National Botanical Research Institute, Lucknow for providing the necessary facility. The authors are thankful to the Head, Department of Botany, D.D.U Gorakhpur University for providing support. We are also thankful to the Directors and curators of A, BM, BR, CAL, CGE, DD, E, FI, G, LINN, LIV, LE, KIEL, MICH, MO, $\mathrm{NY}, \mathrm{OXE}, \mathrm{P}, \mathrm{K}$ and $\mathrm{W}$ for permission to consult specimens or to access digital images of virtual herbaria. The first author is obliged to the UGC, New Delhi, for providing research fellowship to carry out the research. The second, third and fourth authors are thankful to the CSIR, New Delhi, for providing research funding.

\section{Authors' contributions}

SJ searched all the necessary material and prepared the first draft of the manuscript. ST, DP and RY helped in refining the manuscript. VKM revised the final version of the manuscript. PA supervised the whole work, included her suggestions, modified the manuscript and submitted the manuscript for publication.

\section{Conflict of interests}

The authors declare that they have no competing interests.

\section{References}

1. Raddi G. Agrostografia Brasiliensis: sive enumeratio plantarum ad familias naturales Graminum et ciperoidarum spectantium, quas in Brasilia collegit et descripsit. G. Nerici, Lucca; 1823.

2. Soreng RJ, Peterson PM, Romaschenko K, Davidse G, Teisher JK, Clark LG et al. A worldwide phylogenetic classification of the Poaceae (Gramineae) II: an update and a comparison of two 2015 classifications. J Syst Evol. 2017;55:259-90. https://doi.org/10.1111/jse.12262

3. WCVP. World Checklist of Vascular Plants, version 2.0 Facilitated by the Royal Botanic Gardens, Kew. Published on the Internet; http://wcvp.science.kew.org (Accessed 21.01.2021).

4. Clayton WD, Renvoize SA. Genera graminum - Grasses of the World. The Board of Trustees of the Royal Botanic Gardens, Kew; 1986.

5. Hooker JD. The Flora of British India, Vol. 7. L. Reeve \& Co. Ltd, England; 1896.

6. Bor NL. Notes on Asiatic grasses: XXIV. The genus Arundinella Raddi in India, Burma and Ceylon. Kew Bulletin. 1955;10:377414. https://doi.org/10.2307/4109231

7. Bor NL. Grasses of Burma, Ceylon, India and Pakistan (excluding Bambuseae). Pergamon Press. London; 1960.

8. Moulik S. The grasses and bamboos of India, Vol. 1. Jodhpur: Scientific Publishers; 1997.
9. Kandwal MK, Gupta BK. An update on grass flora of Uttarakhand. Indian J For. 2009;32:657-68.

10. Shaju T. Mohanan N. A new species of Arundinella Raddi (Poaceae) from Kerala, India. Rheedea. 2004;14:47-50. https://doi.org/10.3329/bjpt.v21i2.21354

11. Sunil C, Narayanan M, Parameswaran P, Sivadasan M, Alfarhan A. A new species of Arundinella Raddi (Poaceae) from the Western Ghats, India. Bangladesh J Plant Taxon. 2014; 21(2):15357. https://doi.org/10.3329/bjpt.v21i2.21354

12. Sunil CN, Naveen Kumar VV. A new species of Arundinella (Poaceae: Panicoideae: Arundinelleae) from Kerala, India. Webbia. 2014;69(2):249-52. https://doi.org/10.1080/00837792.2014.966601

13. Sunil CN, Prabhukumar KM, Naveen Kumar VV, Thomas VP, Jose Jubin, Balachandran Indira. Arundinella muthikulamensis (Poaceae), a new species from the Western Ghats of Kerala, $\begin{array}{ll}\text { India. } & \text { Webbia. 2017;72(1):101-04. }\end{array}$ https://doi.org/10.1080/00837792.2017.1287814

14. Kellogg E, Abbott JR, Bawa K, Gandhi K, Kailash BR, Ganeshaiah KN et al. Checklist of the grasses of India. PhytoKeys. 2020;163:1560. https://doi.org/10.3897/phytokeys.163.38393

15. Singh P, Karthigeyan K, Lakshminarasimhan P, Dash SS Endemic Vascular Plants of India. Botanical Survey of India, Kolkata; 2015. p. 294.

16. Turland NJ, Wiersema, JH, Barrie FR, Greuter W, Hawksworth DL, Herendeen PS et al. International Code of Nomenclature for algae, fungi and plants (Shenzhen Code) adopted by the Nineteenth International Botanical Congress Shenzhen, China, July 2017. Regnum Vegetabile 159. Koeltz Botanical Books, Glashütten; 2018. https://doi.org/10.12705/Code.2018

17. Thiers B. Index Herbariorum: a global directory of public herbaria and associated staff. New York Botanical Garden's Virtual Herbarium. Published on the Internet; http://sweetgum.nybg.org/science/ih (Accessed 01.12.2020).

18. Hughes DK. In: 15 Decades Kewensis, Bulletin of Miscellaneous Information, Royal Garden, Kew. 1920;3:108-12.

19. Stafleu FA, Cowan RS. Taxonomic Literature, 4. Regnum Vegetabile (P-Sak.); 1983.

20. Trinius CB. De Graminibus Paniceis. Dissertatio botanica altera. Impensis Academiae Imperialis scientiarum, Saint Petersburg; 1826. p. 62.

21. Nees CGD. Gramineae Juss. In: Steudel EG. Synopsis Plantarum Glumacearum 1. J.B. Metzler, Stuttgartlae; 1854. p. 115.

22. Wallich N. A Numerical List of Dried Specimens of Plants in the East India Company's Museum, Collected under the Superintendence of Dr. Wallich of the Company's Botanic Garden at Calcutta. London; 1829.

23. Stafleu FA. Cowan RS. Taxonomic Literature, 7. Regnum Vegetabile (W-Z.); 1988.

Additional information

Peer review information: Plant Science Today thanks Sectional Editor and the other anonymous reviewers for their contribution to the peer review of this work.

Reprints and permissions information is available at

https://horizonepublishing.com/journals/index.php/PST/open_access_policy

Publisher's Note: Horizon e-Publishing Group remains neutral with regard to jurisdictional claims in published maps and institutional affiliations.

To cite this article: Jaiswal S, Tripathi S, Prasad D, Yadav R, Madhukar V K, Agnihotri P. Notes on the typification of three names in the genus Arundinella Raddi (Poaceae). Plant Science Today. 2021;8(3):541-544. https://doi.org/10.14719/pst.2021.8.3.1153

Plant Science Today, published by Horizon e-Publishing Group, is covered by Scopus, Web of Science, BIOSIS Previews, Clarivate Analytics, etc. See https://horizonepublishing.com/journals/index.php/PST/indexing_abstracting 